\title{
TOURISM STUDIES IN THE HIGHER EDUCATION IN SWEDEN: FOCUSING ON SUSTAINABILITY
}

\author{
Olga MILINCHUK ${ }^{1}$ \\ Zhytomyr State Technological University, Ukraine
}

\begin{abstract}
In this paper the Swedish higher tourism education is presented by analyzing the development of tourism education. Descriptive information of English taught University programs has been collected with a purpose to gain a deeper understanding of the general features of tourism higher education in Sweden. Methodology. The paper is based on a web-based content analysis of Swedish universities' web-sites. In total six master degree programs at five universities were analyzed. Results of the analysis showed that the first Swedish academic program in tourism was opened in 1978 and from its inception tourism education is of growing significance. Instead of the higher number of degree programs in tourism, which are taught in Swedish, there is a limited number of those taught in English. Just one Bachelor Programme is taught in English in International Tourism is developed at Dalarna University and one Ph.D. Programme in Tourism is developed at Mid Sweden University. Master programs related to tourism are offered at Dalarna University, Linnaeus University, Lund University, Mid Sweden University, and Umeå University. Based on the curricula analysis of these programs, five main themes are identified: 1) tourism as a social phenomenon; 2) sustainable development of tourism; 3) tourism destination development; 4) economics of tourism, and 5) tourism through service studies. The findings show that the major university programs in tourism adopt an interdisciplinary approach, which combines elements of social sciences, humanities, and business administration. According to the observed curricula, the view on tourism as on social phenomenon prevails. In the studying process, the concept of sustainable development and classical social concepts such as ethnicity, gender, class, culture, and power relations are widely integrated into different tourism courses, making the programs comprehensive, and attractive for international students. The recognition of the tourism programs is supported by the increasing number of international students obtaining degree program in Sweden. Practical implications. This paper presents the Swedish experience of institutionalization of tourism studies into the higher education, which may be interesting for program administrators, faculty, and prospective graduate students. Value/originality. The analysed data shows the specific features of master's programs in tourism studies and identifies the focusing of Swedish higher education on sustainability.
\end{abstract}

Key words: tourism education, education development, curriculum, master program.

JEL Classification: A23, D83

\section{Introduction}

Sweden has a very long tradition of higher education and some of the best universities in the world can be found here (http://www.universitas21.com/ranking/map). There are 48 higher education institutions in various parts of the country. The total number of qualifications awarded within bachelor and master degree programs in 2014/2015 academic year is 80882 (Swedish Higher Education Authority, 2016). Universities and university colleges are open for Swedes as well as for international students by offering courses and programs in English. Altogether there were 343344 individuals taking first or second-cycle courses and programs during the autumn semester of 2015 (Swedish Higher Education Authority, 2016). Of this number, 33180 were incoming students, which corresponds to almost $10 \%$ of the entire student population. Most of the international students come from Germany, France, and China (Swedish Higher Education Authority, 2016).

Several authorities work together to provide education for Swedish and international students. One of them is a Swedish Council for Higher Education (UHR). It is a governmental agency with the main tasks to provide support and information, to coordinate admissions to higher education, to develop international cooperation and to meet other needs of the education sector. Another institution aimed to ensure the quality of higher education and gather statistics about it is the Swedish High Education Authority (UKÄ). Swedish Institute (SI) provides extensive information to international students about studying at Swedish Universities and

Corresponding author:

${ }^{1}$ Department Management of Organization and Administration, Zhytomyr State Technological University.

E-mail: OlgaMilinchuk@gmail.com 
manages scholarship programs for students from a number of different countries. The author of this paper participated in one of the SI programs and was awarded the scholarship to carry out a research project at European Tourism Research Institute (Mid Sweden University, Östersund). Spending time inside the Swedish education system, particularly exploring tourism education, the author finds important to share her views on tourism programs in Sweden and hopes that it will be useful for program coordinators as well as for future incoming students who are interested in tourism programs.

The aim of this paper is to gain a deeper understanding of the special characteristics of different tourism programs taught in English at Swedish Universities and to summarize the general features of tourism higher education in Sweden, which makes it internationally comprehensive. In order to address this aim, the paper had the following research objectives:

- to collect descriptive information about the higher education system in Sweden;

- to analyse tourism education development in Sweden;

- to discuss special characteristics of English taught tourism programs at Swedish universities.

The general method is a web-based content analysis of publicly available information on Swedish universities' web-sites. The selection of six master programs for this study is taken based on tourism profile and English language criteria. By gathering publicly available information, this paper seeks to represent the current state of the first and second cycle tourism education programs in Sweden.

\section{Development of tourism higher education in Sweden: a literature review}

Tourism education is of growing significance. From its inception in the 1960s, it emerged both as an area of study in its own right and as a subject for study up to diploma and degree level for research (Airey, 2005). In Sweden, the first academic program in tourism was opened in 1978. As Anders Steene, one of the founders of tourism studies in Sweden, described in his article "till 1978, just a few courses in ticketing at travel agencies and some vocational schools for hotel and restaurants" existed in Sweden as well as in Norway and Denmark (Steene, 2012: p. 148). The situation changed in 1975 when the Swedish Government and Parliament made decisions to establish a Tourism Council "with the task of marketing Sweden as a tourist destination and to expand higher education with essentially a college in every country" (Steen, 2012: p. 148). According to the first decision (Regeringens proposition, 1975:9) tourism was recognized "as a key economic sector in the Swedish economy” (Steene, 2012: p. 148). The second decision (Regeringens proposition 1975:47) "gave Sweden 12 new colleges in addition to the six already existing universities" (Steen, 2012: p. 148). With this legislative base, the possibility was created to develop new courses at new universities and university colleges. The idea to develop tourism programs came up at three colleges - Östersund and Borlänge in the north, and Kalmar in the south of Sweden - mainly because all of them were located in popular tourist areas since Östersund and Borlänge had developed winter mountain tourism and Kalmar had summer tourism (Steene, 2012).

The newly started Swedish Tourist Board in 1975 (Regeringens proposition 1975:46) gave an institutional support to create the best possible courses in tourism based on local conditions. As a result, "in autumn 1978, the first students started their studies in tourism at the three colleges" (Steen, 2012: p. 150). From 1978 till 1992, the duration of the tourism program was two years. In 1991/1992 academic year the Swedish University and College Office (UHÄ) extended tourism study program from two to three years and gave the opportunity to obtain a Bachelor of Science Degree in Tourism (Steen, 2012). To the three mentioned colleges in 1980's, two more programs in tourism were opened at Karlstad University College and at Gothenburg University (Steen, 2012). Throughout 1990's and early 2000's, the number of programs and universities has increased tremendously. In 2008, there were 30 programs in tourism studies in 13 locations, of which seven programs were already at Master's level (Andersson, 2008).

With an aim to answer the question of what do students study within tourism programs, it is important to analyse curricula. The issues of tourism curricula design existed from the moment tourism became an independent area of study. The development of the first tourism curricula in higher education had vocational origins (Koh, 1995, Holloway, 1995; Tribe, 2005). In Sweden, the first curricula developed "as a mix of traditional academic knowledge and practical skills to meet demands of tourism industry representatives to make the students employable" (Steen, 2012: p. 149). It was supported with a practice of curricula development in the United Kingdom which had mostly vocational character (Airey, Johnson, 1999). The evolution of tourism knowledge from vocational till liberal ends has been described in the range of articles of Tribe (1997, 2000, 2006, 2009). According to Tribe "a vocational curriculum is a curriculum for employment. It is a curriculum to equip students to engage in the vocational world and to participate in it. A liberal curriculum is a curriculum for thinking and reflection" (Tribe, 2005: p. 55). Vocational/ professional or business-oriented curricula, as well as liberal, are still widely spread among the universities around the world (Ayikoru, Tribe, Airey, 2009) and an analysis of special characteristics through a 
subject availability at Swedish universities programs in tourism studies can be important to understand special comprehensive vocational or liberal features of tourism higher education in Sweden.

\section{The general profile}

\section{of master's programs in tourism studies}

There are a lot of possibilities to study in Sweden for the international students, particularly to undertake the program in tourism studies. The international applicants can choose the university program or university college program. The difference is that a university can always offer post-graduate (Ph.D) studies while university colleges cannot. According to the Swedish Higher Education Act (1992:1434), all courses, programs, and qualifications are placed in three cycles: first cycle (Higher Education Diploma, 120 HE credits; Bachelor, $180 \mathrm{HE}$ credits), second cycle (one-year Master, 60 HE credits or two-years Master, $120 \mathrm{HE}$ credits), and third cycle qualifications (Licentiate, $120 \mathrm{HE}$ credits and Doctoral Degree, $240 \mathrm{HE}$ credits). English-taught courses in tourism studies are represented within all three qualifications cycles in Sweden. Today there are more than 30 programs in tourism studies, which belong to the first and second qualification cycles. The programs are offered by Universities in Dalarna/ Borlänge, Gothenburg, Karlstad, Linnaeus/Kalmar, Linköping, Lund/Helsingborg, Malmö, Östersund, Orebro/Grythyttan, Södertörn/Stockholm, and Umeå. The subjects include economics of tourism, tourism management, destination development, tourism hospitality, culture, nature, events, city tourism, leisure and sport management. Just one program of the thirdcycle qualification is offered by Mid Sweden University in collaboration with the European Tourism Research Institute (ETOUR), four-year Ph.D. program in Tourism (Fuchs, Fredman, Ioannides, 2015).

In Table 1, the Swedish universities, which offer master programs related to tourism studies and the link to their web-sites, are shown.

In addition to the aforementioned master programs, there is one the first cycle program in tourism studies, which is called International Tourism Management Programme at Dalarna University. This is only one in Sweden which an English-taught bachelor degree program in tourism studies.
There are common criteria, which form the identity of each higher education program: admission requirements, program curricula, and degree requirement (Lee, Dopson, Ko, 2016). To profile correctly master's program the criteria of institutional affiliation can be added. Due to the institutional background, the academic profile largely differs from university to university.

Based on a web-based review of the key criteria, the main features of master's programs in tourism studies in Sweden can be summarized:

1. Institutional affiliation. The observation of programs shows the variation in institutional affiliation in Sweden. The bachelor and master programs at Dalarna University are located in the School of Technology and Business Studies, as well as a master program at Linnaeus University is located in School of Business and Economics. The master program at Mid Sweden University is affiliated with the Faculty of Human Studies in the Department of Tourism Studies and Geography. The rest of the master programs are affiliated with the Faculty of Social Science in the Department of Service Management and Service Studies at Lund University and in the Department of Geography and Economic History at Umeå University. The "umbrella" of an organizational unit within organizational structure influences the curricula of the programs, affecting its disciplinary variability, the content of every discipline, and the professional specialization of lecturers. This, however, is more obvious within the framework of bachelor's programs and less within master programs curricula, which is also supported by the data of this paper.

2 . According to the general admission requirements, in order to enter the program at Dalarna University and Linnaeus University, the students must have a Bachelor's degree in tourism studies or in another social science. At Lund University, the admission requirements specify that at least $60 \mathrm{HE}$ credits must be within the area of social science, service management, business administration or equivalent. At Umeå University and Mid Sweden University for students to be accepted to the programs, it is necessary to have 90 credits within the main field in human geography, tourism studies or similar tourism-related subject.

Since the selected programs are taught in English, all universities required either TOEFL or IELTS test score or English proficiency equal to B/English 6 at Swedish upper secondary school.

Table 1

The Universities that offer English-taught master programs in tourism studies, 2017

\begin{tabular}{|c|c|c|}
\hline University & University web-site & Programme \\
\hline Dalarna University & http://www.du.se/en/ & Tourism Destination Development \\
& & Economics of Tourism and Events \\
Tourism and Sustainability \\
Linnaeus University & https://lnu.se/en/ & Service management, Tourism \\
Lund University & http://www.lunduniversity.lu.se/ & Tourism \\
Mid Sweden University & https://www.miun.se/en/ & Tourism \\
Umeå University & https://www.umu.se/en/ & \\
\hline
\end{tabular}


There are no other additional admission requirements to enter Swedish master tourism programs such as letters of recommendation, work experience, and prerequisites. At Linnaeus University and Lund University, students can be asked to write a statement of purposes. The absence of additional requirements may indicate that departments feel that work experience is not necessary at the master's level or that tourism studies became a mature field, which engages all levels of students.

3. Every university's program curricula has its own specialization based on multidisciplinary perspective combining elements of social sciences, humanities and arts, business, and other sciences (Tribe, 2016) with a focus on advanced research. The content depends on the main field of study: a degree with the main field of study in tourism studies is offered at Dalarna University, Linnaeus University, Mid Sweden University; with the main field of study in human geography offer Umeå University and Mid Sweden University; with the main field of study in service management with specialization in tourism provide Lund University. The aforementioned institutional affiliation influences specialization as well as the core curricula of the program.

Degree requirements are relatively similar in all master programs. After successful passing of all courses, students are expected to write the master's thesis. In contrast to other countries, where master's programs offer non-thesis options such as a comprehensive final exam or written exam (Lee, Dopson, Ko, 2016), Swedish tourism second-cycle programs are fully researchoriented. But within the one-year master program, the time for writing the thesis has been diminished and under this time constraints, multiple non-thesis options can be implemented in curricula.

The information about the programs and their aims, about subjects of curricula, and degree certificates received by students within the programs is presented in Table 2.

Most of the master programs in tourism studies in Sweden are designed for the students who plan a professional career in public or private sectors, academia, research or consulting. It is supported by the fact that the discipline in methodology, such as qualitative and quantitative methods in tourism / theory and research methods / methods in social sciences / research design and methodology, is incorporated in all programs. There are also additional subjects with an aim to develop research capacities of students such as "Individual Project Studies in Tourism" or "Independent Reading Course". While the courses in methodology are obligatory for the second-cycle studies, there are no other repeated courses. All the courses within the curricula are different and every program has its own unique identity.

The curricula of master programs offered by Swedish Universities in the field of tourism studies have been reviewed and according to the findings the five main thematic studying directions can be identified: 1) tourism as a social phenomenon. This holistic approach is exemplified by tourism programs at Mid Sweden University and at Umeå University; 2) sustainable development of tourism. This is a major concept, which is visible especially in the master program at Linnaeus University, as well as in individual courses at Mid Sweden University, at Dalarna University, at Lund University; 3) tourism destination development. Specific professional skills in destination development are offered as by the program at Dalarna University as well as in individual courses at Lund University and at Umeå University; 4) economics of tourism. Business view on tourism is offered by the program at Dalarna University and in an individual course at Mid Sweden University; 5) tourism through service studies. This is a unique approach to discovering operations in tourism organizations through service sector development offered at Lund University.

It is obvious from the review that the special feature of tourism studies, which is common for all master programs, is the focus on sustainability. One of the programs at Linnaeus University fully integrates the sustainability within all courses of the curricula. According to the information on the website, the scope of the program includes "political and scientific aspects of sustainable development in all courses", within the curricula "gender aspects of social, financial, and environmental sustainability are included as an integrated part of all work, which involves analysing or planning for tourism" (https:// lnu.se/en/programme/tourism-and-sustainabilitymaster-programme/). The suggestion that full integration of sustainability into academic curricula is the best method for hospitality and tourism programs is supported by Boley (2011, p. 24) who writes that "hospitality and tourism undergraduate program should integrate sustainability into all aspects of their curriculum, as well as continue to offer special classes and specific majors that allow students to further explore the subject matter". Therefore, the program is an example of successful incorporation of sustainability into program curricula.

While the international literature has discussed the importance of sustainability within tourism curricula (Rusinko, 2010), the master programs in tourism studies in Sweden has already incorporated the courses of tourism sustainable development (Table 3).

According to the curricula of master programs in tourism studies in Sweden, it can be assumed that the coordinators of the universities' programs are aware of their responsibility to produce postgraduates who are capable of thinking critically about the ways to minimize the negative impacts of the tourism industry and to facilitate the positive ones. 
Table 2

The curricula of Swedish Master Degree Programmes in Tourism Studies

\begin{tabular}{|c|c|c|c|}
\hline The title of university program & The aim of the program & Subjects & Degree Certificate \\
\hline $\begin{array}{l}\text { One-year Master Programme } \\
\text { in Tourism Destination } \\
\text { Development at Dalarna } \\
\text { University }\end{array}$ & $\begin{array}{l}\text { to achieve a broad } \\
\text { understanding of the } \\
\text { opportunities and } \\
\text { limitations that come } \\
\text { with developing tourism } \\
\text { destinations in a sustainable } \\
\text { way }\end{array}$ & $\begin{array}{l}\text { Semester 1 } \\
\text { - Sustainable Destination Development } \\
\text { - Event Tourism - Planning, Marketing, } \\
\text { Evaluation } \\
\text { - Managing and Interpreting Natural and } \\
\text { Cultural Sites } \\
\text { - Place and Destination Marketing } \\
\text { Semester } 2 \\
\text { - Theory and Research Methods } \\
\text { - Degree Thesis in Tourism }\end{array}$ & $\begin{array}{l}\text { Degree of Master of Science } \\
{[60 \text { credits }], \text { Main field of }} \\
\text { study: Tourism Studies }\end{array}$ \\
\hline $\begin{array}{l}\text { One-year Master Programme } \\
\text { in Economics of Tourism and } \\
\text { Events at Dalarna University }\end{array}$ & $\begin{array}{l}\text { to acquire the tools for } \\
\text { economic analysis and } \\
\text { apply them to public and } \\
\text { private policy-making } \\
\text { related to tourism and } \\
\text { events }\end{array}$ & $\begin{array}{l}\text { Semester } 1 \\
\text { - Economics of Tourism } \\
\text { - Econometrics } \\
\text { - Event Tourism } \\
\text { - Economics of Leadership } \\
\text { Semester } 2 \\
\text { - Advanced Microeconomics } \\
\text { - Welfare Economic Analysis of Public } \\
\text { Policy } \\
\text { - Master Thesis in Economics }\end{array}$ & $\begin{array}{l}\text { Degree of Master of Science } \\
{[60 \text { credits }] \text {, Main field of }} \\
\text { study: Economics }\end{array}$ \\
\hline $\begin{array}{l}\text { One-year Master Programme in } \\
\text { Tourism and Sustainability at } \\
\text { Linnaeus University }\end{array}$ & $\begin{array}{l}\text { to provide a comprehensive } \\
\text { specialization in social, } \\
\text { cultural, economic, and } \\
\text { environmental aspects of } \\
\text { tourism in a sustainability } \\
\text { perspective, including } \\
\text { sustainable development }\end{array}$ & $\begin{array}{l}\text { Semester } 1 \\
\text { - Tourism Studies and Tourism Theory } \\
\text { - Tourism and Anthropocene } \\
\text { - Individual Project in Tourism Studies } \\
\text { Semester } 2 \\
\text { - Evaluation and Planning of Tourism } \\
\text { Sustainability } \\
\text { - Methodology } \\
\text { - Tourism Studies, Master's thesis }\end{array}$ & $\begin{array}{l}\text { Degree of Master of } \\
\text { Science }[60 \text { credits] with } \\
\text { specialization in sustainability, } \\
\text { Main field of study: Tourism } \\
\text { Studies }\end{array}$ \\
\hline $\begin{array}{l}\text { Two-year Master Programme in } \\
\text { Service Management, Tourism } \\
\text { at Lund University }\end{array}$ & $\begin{array}{l}\text { to gain industry-relevant } \\
\text { knowledge about } \\
\text { management and leadership } \\
\text { in the service sector with a } \\
\text { focus on tourism }\end{array}$ & $\begin{array}{l}\text { Semester 1 } \\
\text { - Service Management: Theory - } \\
\text { Development and Traditions } \\
\text { - Managing Service Organizations } \\
\text { Semester } 2 \\
\text { - Methods in Social Sciences } \\
\text { - Destination Development and Marketing } \\
\text { Semester } 3 \\
\text { - Service Studies: Perspectives on } \\
\text { Sustainability } \\
\text { - Value Creation and Innovation in Tourism } \\
\text { Semester } 4 \\
\text { - Master Thesis in Service Management }\end{array}$ & $\begin{array}{l}\text { Degree of Master of Science } \\
{[120 \text { credits }], \text { Main field of }} \\
\text { study: } \\
\text { Service Management with a } \\
\text { specialization in Tourism }\end{array}$ \\
\hline $\begin{array}{l}\text { Two-year Master Programme } \\
\text { in Tourism at Mid Sweden } \\
\text { University** }\end{array}$ & $\begin{array}{l}\text { to provide with thorough } \\
\text { knowledge about the } \\
\text { subject allowing them to } \\
\text { develop the ability to carry } \\
\text { out independent scientific } \\
\text { work and to develop } \\
\text { skills necessary to find } \\
\text { employment worldwide }\end{array}$ & $\begin{array}{l}\text { Semester } 1 \\
\text { - Tourism in a Changing World } \\
\text { - Tourism and Sustainability Agenda } \\
\text { - Tourism Management and Economics } \\
\text { - Quantitative Methods in Tourism } \\
\text { Semester } 2 \\
\text { - Qualitative Methods in Tourism } \\
\text { - Independent Reading Course } \\
\text { - Applied Research (Fieldwork Project) } \\
\text { Semester } 3 \\
\text { Internship or Exchange at another } \\
\text { University } \\
\text { Semester } 4 \\
\text { Master Thesis in Tourism Studies/Human } \\
\text { Geography }\end{array}$ & $\begin{array}{l}\text { Degree of Master of Science } \\
\text { [120 credits], Main field of } \\
\text { study: Tourism Studies } \\
\text { or Human Geography }\end{array}$ \\
\hline $\begin{array}{l}\text { Two-year Master Programme in } \\
\text { Tourism at Umeå University** }\end{array}$ & $\begin{array}{l}\text { The program focuses } \\
\text { on how tourism affects } \\
\text { destinations and the } \\
\text { consequences tourism have } \\
\text { for societal development }\end{array}$ & $\begin{array}{l}\text { Semester } 1 \\
\text { - Tourism } \\
\text { - Destinations and Regional Development } \\
\text { Semester } 2 \\
\text { - Population and Mobility } \\
\text { - Methods in Social Science } \\
\text { Semester } 3 \\
\text { - Tourism and Geography } \\
\text { - Research Design and Methodology } \\
\text { Semester } 4 \\
\text { Master Thesis in Human Geography }\end{array}$ & $\begin{array}{l}\text { Degree of Master of Science } \\
\text { [120 credits], Main field of } \\
\text { study: } \\
\text { Human Geography, } \\
\text { Specialization: Tourism }\end{array}$ \\
\hline
\end{tabular}

Source: web-based content analysis of announced programs for 2017/2018 AY and 2017/2019 AY

${ }^{* *}$ Mid Sweden university and Umeå University offer one- and two-year master programs in parallel 
Table 3

The courses with sustainability agenda within curricula of Swedish Master Degree Programmes in Tourism Studies

\begin{tabular}{|l|l|l|}
\hline \multicolumn{1}{|c|}{ The title of university program } & \multicolumn{1}{|c|}{ The course } & \multicolumn{1}{c|}{ The aim of the course } \\
\hline $\begin{array}{l}\text { One-year Master Programme in Tourism } \\
\text { Destination Development at Dalarna } \\
\text { University }\end{array}$ & $\begin{array}{l}\text { Sustainable Destination } \\
\text { Development }\end{array}$ & $\begin{array}{l}\text { The course enables students critically evaluate developmental } \\
\text { as well as managerial options in terms of destination } \\
\text { sustainability; to analyse and evaluate the conditions for } \\
\text { sustainable tourism planning in specified geographical } \\
\text { contexts; to discuss research issues within the field of } \\
\text { sustainable destination development. }\end{array}$ \\
\hline $\begin{array}{l}\text { Two-year Master Programme in Service } \\
\text { Management, Tourism at Lund University }\end{array}$ & $\begin{array}{l}\text { Service Studies: Perspectives } \\
\text { on Sustainability }\end{array}$ & $\begin{array}{l}\text { The course enables students to understand, explain, and } \\
\text { analyse the meaning of sustainability in the service sector, } \\
\text { including cultural, social, financial, environmental, and } \\
\text { ecological conditions and implications, to work within actual } \\
\text { sustainability projects related to service organizations. }\end{array}$ \\
$\begin{array}{l}\text { One- and two-year Master Programme in } \\
\text { Tourism at Mid Sweden University }\end{array}$ & $\begin{array}{l}\text { Tourism and Sustainability } \\
\text { Agenda }\end{array}$ & $\begin{array}{l}\text { The course provides students with a holistic understanding of } \\
\text { the sustainability agenda (cultural, economic, environmental, } \\
\text { and social dimensions) and the role of tourism in it; equip } \\
\text { students with applied tools to critically analyse, challenge and } \\
\text { suggest improvements in current sustainable tourism practices. }\end{array}$ \\
\hline
\end{tabular}

\section{Discussion and conclusion}

The purpose of this paper was to provide a descriptive general profile of tourism higher education programs in Sweden. With this aim in the paper, the development of tourism studies in higher education was followed as well as the master's tourism programs and their core curricula were analysed. According to the content analysis of the second-cycle programs in Sweden, which are entirely taught in English, there are a lot of different opportunities to gain a deep knowledge in tourism studies from interdisciplinary liberal perspective. The accent in the second-cycle programs is made on disciplines in methodology to enable students to produce, analyse, and present research results. However, the content of the programs shows a lack of specialization in special interest tourism such as culture, convention, sport, nature-based, wine- and food-oriented tourism. There is a lack of courses that provide knowledge about strategic development, regional tourism planning, innovation, e-tourism and other courses with a view on modern tourism in a changing world. Nonetheless, most of the relevant issues can be elaborated on during the process of writing an independent thesis what gives the students privilege of the advanced studies.

Variability of the courses within master tourism programs in Sweden shows that there are no narrow vocational curricula. Except for the Programme in Economics at Dalarna University, all programs cultivate the view on tourism as on a social phenomenon without a specific direct integration to business. For example, the curricula at Linnaeus University, Mid Sweden University, and Umeå University encompassed more liberal approach through such courses as Tourism and Anthropocene, Tourism in a Changing World, and Population, and Mobility. Nonetheless, the issues related to destination development within the Programme at Dalarna University and service-oriented studies at Lund University can be viewed as vocational.

Therefore, the main specific characteristic of Swedish higher tourism education is a social view on tourism as a phenomenon instead of business-oriented perspective, which is still rather widespread in curricula in developing countries. Another specific feature of tourism master programs in Sweden is a strong focus on sustainability in social, economic and environment aspects of tourism. The topic of sustainability became the forefront topic within Swedish society and has also trickled down to the university level. Within all programs, a view on tourism, which has a sustainable vector of development, is observed. Sustainable style of living of Swedish society and the higher education programs with focusing on sustainability formulated a competitive edge of postgraduate studying in Sweden.

Acknowledgements. This publication has been produced during my scholarship period at European Tourism Research Institute at Mid Sweden University, thanks to a Swedish Institute scholarship. The insightful comments made by Lusine Margaryan and Sandra WallReinius are sincerely appreciated.

\section{References:}

Airey, D., \& Johnson, S. (1999). The content of tourism degree courses in the UK. Tourism Management, 20(2), 229-235.

Andersson, B. (2008). Turismutbilndingar 2008. Med perspektiv på utbud och efterfrågan. Tillväxtverket. Rapport 0001. Stockholm. 
Ayikoru, M., Tribe, J., \& Airey, D. (2009). Reading tourism education: Neoliberalism unveiled. Annals of Tourism Research, 36(2), 191-221.

Boley, B. B. (2011). Sustainability in hospitality and tourism education: towards an integrated curriculum. Journal of Hospitality \& Tourism Education, 23(4), 22-31.

Koh, K. (1995). Designing the four-year tourism management curriculum: A marketing approach. Journal of Travel Research, 34(1), 68-72.

Holloway, C. (1995). Towards a core curriculum for tourism: A discussion paper. National Liaison Group for Higher Education in Tourism.

Lee, M. J., Dopson, L., \& Ko, S. (2016). Graduate study in hospitality management in the United States: master of science programs. Journal of Teaching in Travel \& Tourism, 16(3), 213-227.

Rusinko, C. A. (2010). Integrating sustainability in higher education: a generic matrix. International Journal of Sustainability in Higher Education, 11(3), 250-259.

Steene, A. (2014). Tourism education in Sweden: Past, Present and Future. Browser Download This Paper.

Tribe, J. (1997). The indiscipline of tourism. Annals of tourism research, 24(3), 638-657

Tribe, J. (2000). Balancing the vocational: The theory and practice of liberal education in tourism. Tourism and Hospitality Research, 2(1), 8-25.

Tribe, J. (2006). The truth about tourism. Annals of tourism research, 33(2), 360-381.

Tribe, J. (2005). Tourism, knowledge and the curriculum. An international handbook of tourism education, 47-60. Tribe, J., \& Liburd, J. J. (2016). The tourism knowledge system. Annals of Tourism Research, 57, 44-61.

Fuchs, M., Fredman, P., \& Ioannides, D. (2015). Tourism PhD Studies. In Tourism Education: Global Issues and Trends (pp. 61-79). Emerald Group Publishing Limited.

Higher Education in Sweden. Status Report 2016:11. Retrieved May, 15, 2017, from http://english.uka.se/ download/18.5d85793915901d205f916275/1487932593678/status-report-statistics-higher-educationsweden-2016.pdf

Regeringens proposition 1975:9 Proposition om reformering av högskoleutbildningen. Retrieved May, 15, 2017, from http://data.riksdagen.se/fil/4396e661-24c2-4323-8ad2-b04c559bda7f

Regeringens proposition 1975:4 Proposition om planering och samordning av samhällets insatser för rekreation och turism, Retrieved May, 15, 2017, from http://www.riksdagen.se/sv/dokument-lagar/dokument/proposition/ regeringens-proposition-om-planering-och_FY0346

Regeringens proposition 1975:47 Proposition om inrättande och finansiering av Sveriges turistråd, Retrieved May, 15, 2017, from http://www.riksdagen.se/sv/dokument-lagar/dokument/proposition/regeringens-propositionom-inrattande-och FY0347/html

\section{List of Swedish master programs' websites:}

Master Programme in Tourism Destination Development at Dalarna University -http://www.du.se/en/Studyat-DU/Programmes/One-Year-Master-Programme-in-Tourism-Destination-Development/

Master Programme in Economics of Tourism and Events at Dalarna University -http://www.du.se/en/Studyat-DU/Programmes/Master-Programme-in-Economics-of-Tourism-and- Events-60-credits-/

Bachelor Programme in International Tourism Management at Dalarna University -http://www.du.se/en/itm Master Programme in Tourism and Sustainability at Linnaeus University -https://lnu.se/en/programme/tourismand-sustainability-master-programme/kalmar-international-autumn/

Master Programme in Service Management at Lund University -http://www.lunduniversity.lu.se/lubas/i-uoh-luSASMA-TURI

Master in Tourism (two year) at Mid Sweden University - https://www.miun.se/en/education/programmes/ business-law-social-sciences-and-tourism/master-in-tourism-120-higher-education-credits/about-the-program/

Master in Tourism (one year) at Mid Sweden University - https://www.miun.se/en/education/programmes/ business-law-social-sciences-and-tourism/master-one-year-in-tourism-studies-60-credits/about-the-program/

Master Programme in Tourism at Umeå University - https://www.umu.se/en/education/master/mastersprogramme-in-tourism/

\section{List of support state institutions websites:}

Swedish Council for Higher Education (UHR) - https://www.uhr.se/en/start/

Swedish High Education Authority (UKÄ) - http://english.uka.se/

Swedish Institute (SI) - https://eng.si.se/

Swedish Institute official resource of studying in Sweden - https://studyinsweden.se/

Swedish Council for Higher Education official recourse - http://www.studera.nu/startpage/higher-educationstudies/higher-education-in-sweden/study-levels-and-degrees/

Central Application Portal of University Admission in Sweden -https://www.universityadmissions.se/intl/start The Leading Global Network for Research Universities for the 21st century "Universitas 21" http://www.universitas21.com/ranking/map 


\section{Ольга МИлИнчук}

\section{ТУРИЗМОЛОГИЯ В ВЫСШЕМ ОБРАЗОВАНИИ ШВЕЦИИ: ФОКУС НА УСТОЙЧИВОСТЬ}

Аннотация. В статье рассмотрено особенности высшего образования в сфере туризма Швеции путем анализа истории его развития и сбора информации о существующих англоязычных университетских программах. Целью написания статьи является получения более глубокой характеристики туристического высшего образования в Швеции. Методология. Статья базируется на анализе содержания Интернетресурсов шведских университетов. В целом проанализировано шесть магистерских программ. Результаты показывают, что первая шведская академическая программа в сере туризма была открыта в 1978 году и с этого момента высшее образование в сфере туризма стремительно развивалось. Сегодня в Швеции существует значительное количество магистерских программ в сфере туризма, в некоторых из них преподавание ведется на английском. В высшем образовании Швеции представлена лишь одна бакалаврская программа «Международный туризм» в университете Даларны и одна докторская программа в Центральношведском университете, где преподавание ведется на английском. Англоязычные магистерские программы в сфере туризма предлагаютуниверситет Даларны, университетЛиннаеуса, университет Лунда, Центральношведский университет и университет Умео. На основе анализа рабочих планов указанных магистерских программ было выделено пять основных учебных направления: 1) туризм как социальный феномен; 2) устойчивое развитие туризма; 3) разработка туристических маршрутов; 4) экономика туризма, и 5) туризм в сфере услуг. Результаты показывают, что большинство университетских программ в сфере туризма адоптировали междисциплинарный подход кобучению, что объединяет элементы социальныхи гуманитарных наук, а также бизнес-администрирование. В рассмотренных рабочих планах магистерских программ доминирует взгляд на туризм как на социальный феномен, а в учебный процесс интегрирована как концепция устойчивого развития, так и классические социальные концепции такие, как этничность, гендер, классовые отношения, культура, что делает программы современными, конкурентными и привлекательными для международных студентов. Признание образовательных программ в сфере туризма подтверждает увеличивающееся количество международных студентов, что получают высшее образование в Швеции. Практическое значение. Статья представляет шведский опыт институционализации туристического высшего образования, что может быть интересным для администраторов учебных программ, преподавателей и перспективных студентов. Значение/оригинальность. Проанализированные данные показывают особенности магистерских программ в сфере туризма и определяют фокусирование шведского высшего образование на вопросах устойчивого развития. 